\title{
Transcription Factor HES-3
}

National Cancer Institute

\section{Source}

National Cancer Institute. Transcription Factor HES-3. NCI Thesaurus. Code C104532.

Transcription factor HES-3 (186 aa, $20 \mathrm{kDa}$ ) is encoded by the human HES3 gene. This protein plays a role in the repression of transcription. 